\title{
FRÅN INDUSTRIMINNE TILL INDUSTRISAMHÄLLETS KULTURARV - TANKAR KRING ETT BETÄNKANDE
}

\author{
Ewa Bergdahl
}

Ett begrepp som fătt stark genomslagskraft under 1990-talet är "kulturarv" och $i$ synnerhet "det industrihistoriska kulturarvet". Begreppet har anammats och inkorporerats både i museernas och myndigheternas terminologi. Det har fätt symbolisera den markering av samtidsinriktning som eftersträvats av de kulturhistoriska institutionerna.

Naturligtvis är det inte bara av opportunistiska skäl. 1990-talets huvudtema har för hela sektorn varit "det industrihistoriska kulturarvet" i kombination med begreppen mångfald, globalisering och marginalisering. Men arbetet med frågorna som rör industrihistoria har förändrats. Intresseinriktningen har förskjutits och från att tidigare ha varit koncentrerad på de fysiska lämningarna i landskapet, byggnader, hus, gruvor, fabriksanläggningar, har arbetet alltmer kommit att koncentreras på verksamheterna, människorna och processerna. "Det industrihistoriska kulturarvet" har blivit till "Industrisamhällets kulturarv".

\section{HUR SER DEN ORGANISATORISKA KARTBILDEN UT?}

En betydelsefull milstolpe i arbetet var inrättandet av en professur i industriminnesforskning vid KTH i Stockholm år 1992. Då hade ett allt bredare arbete ute i landet bland museer, arkiv, forskningsinstitutioner och ideella organisationer resulterat i bildandet av Industribistoriskt forum, som en paraplyorganisation med representanter för olika intressen (näringsliv, arkiv, forskning, museer m.fl.). Där kunde generella frågor kring industriarvets bevarande tas upp till diskussion.

Svenska Industriminnesföreningen hade sedan sin tillkomst i början av 1980-talet fäst uppmärksamheten på det industrihistoriska - kanske främst det teknikhistoriska - kulturarvet under ett tiotal år. Föreningen blev Sveriges organisatoriska representant i den internationella organisationen TICCIH (The International Committee of Conservation of Industrial Heritage) och utgjorde länken mellan de enskilda medlemmarna och världsorganisationen.

Sett i ett internationellt perspektiv kan vi konstatera att intresset för att tillvarata och 
104 bevara industrianläggningar och dokumentera deras historia av naturliga skäl har varit starkast i västeuropa, USA och Kanada. Det var också här som den tekniska utvecklingen gick snabbast och språnget in i ett av IT-teknik präglat samhälle var tydligast. I många andra länder runt om $\mathrm{i}$ världen har frågorna först under de senaste åren kommit upp på agendan, t.ex. i Baltikum och Ryssland, där stora industrianläggningar nu står ödelagda och tomma.

Utbildningen i Industrial Archaeology i England på 1960-talet var en viktig inspirationskälla för många. Tankarna fick även fotfäste på ett tidigt stadium i Skandinavien framför allt genom enskilda forskares engagemang. Intresset för industrins historia var dock i första hand inriktat antingen på dess teknikhistoriska aspekter eller på industriarkitekturens specifika kulturhistoriska värden.

Under 1970-talet utvecklades den regionala kulturmiljövården, KMV-program skrevs i kommunerna och bevarandet av det fysiska kulturarvet inkluderade allt fler kategorier av byggnader, däribland kom även en del industriella anläggningar att räknas till de bevarandevärda kulturmiljöerna.

En annan viktig verksamhet - som etablerades på 70-talet - för arbetet med industrisamhällets kulturarv (även om det inte formulerades så) var SAMDOK, museinätverket för samtidsdokumentation med fotodokumentationer och intervjuer med anställda på olika arbetsplatser i Sverige. Detta arbete skedde företrädesvis i museernas regi och var etnologiskt inriktat.

Svenska Industriminnesföreningen gav under 1980-talet ut tidskriften TEKNIK $\mho K U L$ $T U R$, där bevarandeproblematik, större industrihistoriska projekt och även viss internationell debatt presenterades för museitjänstemän, forskare och andra enskilda med intresse för frågorna. Tidskriften hade trots sin smala spridning och sitt enkla utförande, stor betydelse för att frågorna hölls vid liv inom kulturarvsinstitutionerna.

Inom kulturminnesvården skedde under 1900-talets tre sista decennier en markerad och tydlig begreppsförskjutning, som vidgade verksamhetsfältet först från byggnader och enskilda anläggningar (kulturminnesvård) till miljöer och landskap (kulturmiljövård) och därefter till hela det historiska materialet i form av immateriella och materiella spår av mänskligt liv. Begreppet kulturarv blev allt vanligare i den offentliga debatten.

Motsvarande intresseförskjutning skedde även när det gäller industrihistorien. Mycket kraft hade hittills lagts på bevarandeaspekterna och de frågor som förknippades med hur de fysiska anläggningarna skulle tillvaratas, men en kombination av praktisk verklighet och fördjupade studier vidgade även synfältet över det industriella kulturarvet och så småningom tydliggjordes också hur detta är oupplösligt förenat med framväxten av industrisamhället under 1900-talet.

En rad nya frågeställningar kom därvid att fokuseras. En av dem var frågan om hur den här typen av anläggningar skulle kunna bevaras för framtiden. Det gällde inte längre enbart hus utan i allt högre grad hela infrastrukturella system som inkluderade transportnät, energitillgångar, produktionsanläggningar, men även bostadsområden, och offentliga rum för det sociala livet. Bevarandeproblematiken kom alltså att utvidgas till att gälla hela det komplexa samhälle, som har växt fram under 1900-talet. Avgränsningarna var problematiska. Likaså frågan om vilka kriterier som skulle vara avgörande för urvalen.

Flera av de statliga museerna insåg tidigt att 
de knappast ensamma utifrån sina specialinriktningar kunde hantera industrisamhällets kulturarv. Riksantikvarieämbetet, Tekniska museet, Arbetets museum och Nordiska museet bildade på informell grund en gemensam diskussionsplattform för att skapa bättre samverkan och mer gränsöverskridande arbetssätt mellan institutionerna.

Gräv där du står- rörelsen upplevde under 1990-talet en renässans och många nya former av museer bildades (arbetslivsmuseer, ekomuseer) som svar på några av de frågor som hade väckts. Det ekomuseala arbetssättet pekade framför allt på hur det industrihistoriska kulturarvet är historien om det mångfacetterade industrisamhället, som för att bevaras och beskrivas krävde ny metodik. Traditionell insamling efter generella urvalskriterier var inte längre möjlig. Industrisamhällets fysiska anläggningar låter inte flytta på sig på samma sätt som bondesamhällets timrade hus och byggnader.

Det lokala engagemanget som växte fram, de ideella krafterna och eldsjälarna krävde också inflytande över urvalsprocessen. Frågan om hur vi skulle hantera industrisamhällets kulturarv blev till stor del en demokratifråga. Diskussionerna om vem som hade tolkningsföreträde var livliga. Lokala ideella entusiaster, med praktiska kunskaper om maskiner och processer stod plötsligt mot teoretiskt skolade antikvarier, som - med sin generella överblick och sitt nationella ansvar för hela landets bevarandearbete - hade helt andra uppfattningar inte bara om vad som var värt att bevara, utan även hur detta skulle låta sig göras.

Gamla beprövade urvalskriterier luckrades upp och nya tillkom. Man började tala om upplevelsevärden, symbolvärden och sociala värden som komplement till unicitet och representativitet. Kulturarvsinstitutionerna kun- de plötsligt inte ensamma och med självklar105 het hantera frågorna. Debatten fördes också delvis utanför de gängse kanalerna. Vid sekelskiftet 2000 gjordes jämförelser med hur hembygdsrörelsen hade växt fram kring det förra sekelskiftet som ett svar på behovet hos många människor att spara och säkerställa delar av det arv som det agrara samhället innehöll och som många då upplevde som hotat.

När kulturdepartementet i maj 1998 tillsatte Erik Hofrén som enmansutredare för att lämna förslag om hur det industrihistoriska kulturarvet skulle hanteras, var således en del av frågorna redan väckta och arbetet påbörjat. Utredningen utmynnade i ett betänkande (SOU 1999:18) med titeln, Frågor till det industriella sambället. Betänkandet blev ovanligt. Dels på grund av sin oprententiösa form men framför allt därför att det istället för att dra slutsatser och ställa förslag, formulerade en rad frågor. Här fanns inte stipulerat konkreta åtgärdsprogram för regeringen att arbeta vidare efter, utan 21 frågor, som istället pekade ut en rad områden och aspekter på industrisamhällets kulturarv, där det framtida bevarandearbetet bör koncentreras.

Viktigast av allt är kanske att utredningen konsekvent byter namn på det "industrihistoriska kulturarvet" och kallar det för "industrisamhällets kulturarv" . Därmed inkluderas hela det svenska folkhemsbygget som ju var resultat av den politiska och ekonomiska utvecklingen i Sverige under 1900-talet.

Det vanliga och alldagliga som präglar de mellansvenska bruksorterna, har ansetts leda fram till folkhemsidén. Men utredningen lyfter framför allt fram det svenska stationssamhället som ett exempel på detta vardagliga och samtidigt generella och typiska. Hofrén pekar även på att storskaligheten är ett specifikt kännetecken för industrisamhället, och att den 
Ewa Bergdahl

106 stora skalan i sig innebär både möjligheter och problem.

Institutionerna bör i högre grad samverka i arbetet med att bevara, berika och bruka industrisamhällets kulturarv. Samverkan blir alltmer nödvändig ju komplexare de områden och frågor är som ska hanteras. Men institutionerna måste även i allt större utsträckning samarbeta med medborgarna och med de ideella organisationer och lokala arbetslivsmuseer, som växer fram och som arbetar med det lokala industrihistoriska arvet.

Men kanske allra viktigast i utredningen är att de många frågorna som ställs, tydliggör att arbetet med det industrihistoriska kulturarvet hittills utförts på ett exkluderande och traditionellt sätt. Museer och andra kulturarvsinstitutioner behöver utveckla ett självkritiskt och analytiskt synsätt på hur de är medskapare till det kulturarv de är satta att bevara.

För vem görs urvalen och vilka inkluderas $\mathrm{i}$ kulturarvsbegreppet? Vems berättelser bevaras? Aspekter som jämställdhet, utanförskap och underrepresentation förs in i diskussionen. Okonventionella arbetsformer och lyhördhet för olika former av egna lokala initiativ och särintressen måste, enligt utredaren, ges mycket större plats. Begreppet delaktighet diskuteras ingående och blir ett av nyckelorden. Hanterandet av industrisamhällets kulturarv nu och i framtiden är alltså ytterst en fråga om demokrati och inflytande för de många.

\section{DELEGATIONEN FÖR INDUSTRISAM- HÄLLETS KULTURARV}

Utredningen bildade utgångspunkt för den delegation som kulturdepartementet inrättade i juli 1999. Delegationen fick i uppdrag att under en treårsperiod svara för departementets satsning på industrisamhällets kulturarv

och fördelade under perioden $24,5 \mathrm{mkr}$ till olika projekt med industriarvsinriktning.

Förra året sammanfattade delegationen sitt uppdrag och skrev sitt slutbetänkande Industrisambällets kulturarv (SOU 2002:67). Det är intressant att ställa slutredovisningen i ett jämförande perspektiv mot enmansutredningens frågor, men också att i efterhand läsa delegationens egen tolkning av sitt uppdrag och jämföra med de resultat som har åstadkommits genom regeringens treårssatsning.

Delegationens tolkning av sitt uppdrag formulerades på den hemsida som upprättades strax efter att arbetet påbörjats. Här kunde man t.ex. läsa att delegationen ville initiera undersökningar och sammanställningar av redan gjorda undersökningar om över- och underrepresentation, att man vill initiera samarbete mellan olika aktörer, arrangera seminarier, väcka opinion, uppmärksamma och belysa frågorna genom massmedia, stödja forskning om kulturarvets historiska roll i industrisamhället, stödja sådana projekt som fokuserar på samhällets "mörka sidor", ekonomiskt stödja arbetslivsmuseerna och synliggöra de ideella krafternas insatser, skapa samverkan och samsyn mellan institutioner och allmänhet, stödja projekt som syftar till att öka dialogen mellan olika grupper samt slutligen bejaka mångfalden röster och låta marginaliserade grupper komma till tals.

Det som genomsyrar detta målsättningsdokument, där delegationen tolkar sitt uppdrag och anger vilka tillvägagångssätt man tänker arbeta med, är samverkanssträvan. Samverkan mellan kulturarvsinstitutioner, samverkan mellan olika grupper av människor, mellan myndigheter och enskilda och mellan arbetsmarknadens parter. Samtidigt påpekas att "industrisamhällets historia kretsar såväl kring samförstånd som konflikter. Denna dubbelhet liksom 
de politiska aspekterna på industrisamhället ska komma till uttryck/gestaltas i kulturarvet."

Slutbetänkandet har blivit en intressant skrift som sönderfaller i två separata delar. Dels en essäsamling med bidrag från en rad personer både inom och utanför delegationens krets. Artiklarna speglar industrisamhällets mångfald och det stora urval av utgångspunkter som står till buds. De är mer att betrakta som litterära, individuella, bidrag där artikelförfattarna fokuserar på områden och aspekter som de själva har valt ut.

I den mer traditionella delen av betänkandet redovisas de tre årens resultat. Vilka projekt har givits statliga medel för att förverkligas? Hur har delegationen resonerat vid bidragsutdelningen, för som $\mathrm{i}$ alla liknande situationer har det funnits ett väldigt behov av ekonomiskt stöd långt utöver de miljoner som stod till buds. Det är lätt att konstatera att den allra största delen av projektmedlen gått till stora projekt som drivits av centrala kulturarvsinstitutioner. Ett fătal av dessa finns detaljredovisade i slutbetänkandet, men med tanke på storleken på dessa satsningar hade det varit intressant att få ta del av flera slutredovisningar. Arbetarrörelsens Arkiv har tilldelats 1.8 milj kr för depåverksamhet i Grängesberg. Innovativt och nyskapande? Sveriges Hembygdsförbund har fătt $990.000 \mathrm{kr}$ för ett projekt med det originella namnet; "Industrisamhällets kulturarv". Vad har det haft för specifikt fokus? ABF har tagit upp grävrörelsens spade och beviljats 1.5 milj kr för det fortsatta utforskandet av de lokala arbetsplatserna. Vilka är resultaten? CSIK (Centrum för Studier av det Industriella Kulturarvet) har tilldelats 875.000 kr. Är denna centrumbildning, som är knuten till ett av våra universitet, ett projekt i sig?

En mycket stor del av de beviljade medlen har gått till arrangerandet av seminarier och 107 konferenser. Många av seminarierna har haft ett likartat innehåll. Kanske har man tänkt att de endast har regional täckning, men Sverige är ett litet land och på många av dessa konferenser och kunskapsseminarier har samma personer hållit samma föredrag.

Mest anmärkningsvärt är nog att det saknas kvalitativa analyser av resultaten av de genomförda projekten. Detta är också något som två av delegationens medlemmar i särskilda yttranden har påpekat. Man anser att de förslag till fortsatta insatser som delegationen föreslår är alltför löst grundade, att det knappast är motiverat att föreslå en fortsatt projektsatsning på basis av enbart den redovisning som gjorts och att den översyn av hela kulturarvssektorn som föreslås står i bjärt kontrast till att man samtidigt förespråkar mångfald och förordar många olika, men samverkande, aktörer när det gäller bevarandet av industrisamhällets kulturarv.

I slutbetänkandet konstaterar man, att satsningarna inte nått ut till lokala aktörer och att näringslivet är dåligt representerat både i projektlistorna och i seminarierna. Man noterar vidare att det genomgående har saknats representanter från kommunerna. Men det är knappast bristande intresse vare sig från de politiska instanserna i kommunerna eller från museer och kulturförvaltningar som är orsaken. Snarare har delegationens arbete genom att koncentrera sina kontaktytor i första hand mot länsstyrelserna fått denna ofrivilliga slagsida. Informationen från de regionala nivåerna når inte ut. En annan orsak är kommunernas minst sagt prekära ekonomiska situation, som särskilt under de senaste fem åren kraftigt förvärrats.

Dock - de kommunala museerna bedriver i samverkan med kulturförvaltningarna ett dag- 
108 ligt strävsamt opinionsarbete, där frågor som rör industrisamhällets kulturarv ständigt står på dagordningen. De samarbetar med nämnder och förvaltningskontor som i sin dagliga praktiska verklighet hanterar den fysiska planeringen av lokalsamhället. I den lokala dagliga praktiken i kommunerna, i en levande dialog med och mellan medborgarna, finns faktiskt alla de frågor som utredningen förde fram. Här borde kanske Industriarvsdelegationens arbete ha börjat och här borde det ha avslutats.

\section{SUMMARY}

From industrial monument to industrial heritage

In 1998 the Minister of Culture called on professor Erik Hofrén to propose government measures to further the protection of industrial heritage.

From local initiatives to protect and preserve old industrial sites, notably related to mining and metallurgical installations, a true movement concerned with this history emerged and gained strength in the last decades of the 20th century. Within this movement the concept of industrial archæology has been adopted to include a wider environment than the isolated factory. This development constitutes the background to the government action.

In 1999 Erik Hofrén's proposal was published as a departmental report (SOU 1999:18) with the title Questions to the industrial society. This was an unusual approach to the task, which instead of offering a con- crete programme, indicated areas and aspects of concern. A crucial shift in concepts was proposed: 'the heritage of industrial history' should be replaced by 'the heritage of industrial society'. Thus the wider implications of the introduction of industrial technology and production systems for societal change were stressed.

As a result of the report a committee was set up by the Minister in 1999 to function for three years on behalf of the government with the aim of initiating research, supporting initiatives and stimulating interest and institutional cooperation in the field.

The committee submitted a report on its activities in 2002, The cultural heritage of the industrial society (SOU 2002:67). An attempt is made in this article to review the two reports and evaluate their outcome. It is evident that industrial heritage is a complex and difficult field, full of controversial issues which make cooperation between industrialists, workers' organisations, public institutions and the local citizens complicated. However, it is pointed out, local museums have a key role to play and their significance has not been sufficiently valued by the committee.

\section{Ewa Bergdahl}

museum director

Adr. Norköpings stadsmuseum

Väströtegatan 21

S-602 21 Norrköping

Tel. +4611152625

Fax. +4611107601

E-mail: ewa.bergdahl@norrkoping.se 